\title{
KONFLIK KEWENANGAN PENYIDIKAN ANTARA PENYIDIK POLRI DAN POLISI KEHUTANAN DALAM PENCURIAN KAYU
}

\author{
Rinaldy Amrullah \\ Dosen Bagian Hukum Pidana Fakultas Hukum Universitas Lampung \\ Email : rinaldy.amrulllah@fh.unil.ac.id
}

\begin{abstract}
Abstrak
Penanganan tindak pidana pencurian kayu belum optimal, hal tersebut disebabkan oleh adanya tumpang tindihnya peran sebagai penyidik yang dapat dilakukan oleh Pejabat Pegawai Departemen Kehutanan yang ditunjuk melalui Penyidik Pegawai Negeri Sipil dan Kepolisian Negara Republik Indonesia (Polri). Kondisi tersebut tentunya membawa implikasi bagi Polri yaitu dianggap kurang memiliki kemampuan dalam melakukan penyelidikan dan penyidikan atas kasus pidana.Ketidaklengkapan pengaturan mekanisme penangkapan oleh PPNS kehutanan dan polisi kehutanan dalam undang-undang kehutanan menimbulkan beda persepsi penerapannya bahkan menyebabkan kewenangan tersebut "mandul" sehingga dalam hal tidak tertangkap tangan, PPNS masih meminta bantuan POLRI untuk mengeluarkan surat perintah penangkapan dengan membuat permintaan bantuan penangkapan ke kepolisian terdekat meskipun polisi kehutanan dan PPNS kehutanan sudah memiliki kewenangan itu berdasarkan undang-undang no. 41 tahun 1999 tentang kehutanan.
\end{abstract}

Kata kunci : Kewenangan, penyidik, pencurian kayu.

\section{Pendahuluan}

Indonesia merupakan salah satu negara yang memiliki hutan tropis yang cukup luas. Dari data yang ada, luas hutan tropis Indonesia menduduki tempat ke-3 (ketiga) di dunia setelah Kongo dan Brazil. Kondisi tersebut tentunya menjadikan hutan indonesia sebagai oksigen sekaligus memiliki sumber plasma nutfah yang sangat bermanfaat. Luasnya hutan Indonesia pada dasarnya telah memberikan kontribusi yang positif terhadap pertumbuhan ekonomi nasional. Bahkan lebih dari tiga dekade sektor kehutanan telah menjadi modal utama pembangunan nasional. Namun, di sisi lain kerusakan hutan sebagai akibat pencurian kayu yang dilakukan oleh pihak-pihak yang mencari keuntungan dari hasil hutan semakin memperihatinkan. Salah satu contoh kerusakan hutan (Deforestasi) di 5 (lima) pulau besar sudah mencapai 2,83 juta hektar pertahun.

Sebagai contoh adalah gambaran kerusakan hutan di wilayah Lampung Barat. Berdasarkan data Kementerian Kehutanan mengenai kerusakan hutandi wilayah Lampung Barat akibat praktik pencurian kayu diperkirakan mencapai triliunan per tahun, belum termasuk nilai kerugian dari aspek ekologis seperti musnahnya spesies langka, terganggunya daerah aliran sungai yang berimbas pada kehidupan manusia dan sekitarnya yang berpotensi menimbulkan bencana seperti tanah longsor, banjir, kekeringan serta kebakaran hutan. Berdasarkan data yang diperoleh dari Ditreskrim Polda Lampung, selama 
tahun 2012 kasus pencurian kayu yang menonjol di wilayah Polres Lampung Barat sebanyak 9 kasus. Semakin maraknya tindak pidana pencurian kayu melibatkan peran aktif pelaku dalam memfasilitasi perdagangan kayu hasil pencurian yang dilakukan oleh pelaku-pelaku baik WNI maupun WNA dari beberapa negara tetangga, sehingga sudah merupakan kejahatan transnasional. (Bappenas, 2009). Selain hal tersebut, berkembanganya kegiatan tindak pidana pencurian kayu ditenggarai oleh adanya oknum petugas kehutanan dalam pemberian perizinan dan manipulasi isi dokumen kayu yang berhubungan dengan Administrasi Kayu (Penatausahaan Hasil Hutan Kayu) untuk bisa sampai di Industri maupun untuk di pasarkan di wilayah maupun negara lain. Dengan demikian, tingginya tindak pidana pencurian kayu di wilayah Lampung Barat telah mengurangi penutupan lahan hutan dan membawa pencitraan buruk di mata dunia internasional atas ketidakmampuan pemerintah pusat dan daerah dalam pengelolaan hutan serta ketidakpedulian pemerintahan pusat dan daerah akan pentingnya hutan.

Melihat fenomena tersebut diatas, pemerintah secara yuridis melalui Inpres Nomor 4 Tahun 2005 tentang Pemberantasan Penebangan Kayu secara ilegal di Kawasan Hutan dan Peredarannya di seluruh wilayah Republik Indonesia, bertekad untuk memberantas Illegal Logging sampai keakar-akarnya melalui kerjasama komprehensif dari berbagai Instansi Pemerintah.

Polri sebagai salah satu institusi dalam the criminal justice system yang diberi kewenangan untuk melakukan law enforcement terhadap tindak pidana pencurian kayu tentu saja memainkan peranan yang sangat penting guna melakukan investigasi dalam rangka mengungkap suatu tindak pidana illegal loging yang terjadi secara tuntas. Hal tersebut tentu saja bukanlah persoalan mudah, para pelaku pada umumnya telah sangat matang memperhitungkan resiko yang akan dihadapi bila perbuatannya terungkap. Melarikan diri dan menyembunyikan hasil curiannya adalah hal-hal yang biasanya akan mereka lakukan untuk menghindari diri dari jeratan hukum. Kewenangan dalam pelaksanaan penanganan tindak pidana pencurian kayu terjadi tarik menarik antara Penyidik Pegawai Negeri Sipil (PPNS) dengan penyidik kepolisian.

Menurut KUHP dan UndangUndang No. 8 Tahun 1981, jelas tercantum Polri merupakan satusatunya lembaga yang diberi tugas sebagai penyidik tindak pidana termasuk illegal logging. Selain hal tersebut, Polri pun khususnya Polres Lampung Barat masih dihadapkan dengan beberapa kendala baik kuantitas maupun sumber daya manusia/personel yang masih belum memadai, sarana prasarana dan anggaran yang masih minim serta sistem dan metode/HTCK yang belum optimal, sehingga kewenangan Polri khususnya dalam penanggulangan tindak pidana pencurian kayu belum sesuai dengan harapan. Oleh karena itu, guna menunjang kewenangan Polri dalam penanggulangan pencurian kayu, perlu meningkatkan sumber Daya manusia/personel, kelengkapan sarana dan prasarana, meningkatkan anggaran, meningkatkan sistem dan metode/HTCK serta meningkatkan kerjasama antar instansi terkait guna 
mendukung kebijakan pemerintah dalam pemberantasan tindak pidana illegal logging, sehingga diharapkan terjalin hubungan yang baik yang pada gilirannya dapat sangat bermanfaat dalam melakukan penanggulangan tindak pidana pencurian kayu terkait dengan tugas pencarian, pengangkapan bahkan melacak aset-aset para tersangka sehingga kamtibmas dapat terwujud dengan aman, tertib dan kondusif.

Berdasarkan hal tersebut bagaimana kewenangan penanganan tindak pidana pencurian kayu (illegal logging)"?

\section{Pembahasan}

Penegakan hukum yang berkaitan dengan kasus perusakan lingkungan, pencemaran limbah industri, pencemaran udara dan sebagainya masih jauh dari harapan. Ironisnya lagi, kasus pencemaran dan/atau pengrusakan lingkungan lingkungan yang dilakukan terus menerus terutama pengrusakan kawasan hutan tanpa tindakan yang berarti dari aparat penegak hukum sehingga menambah catatan "hitam" kejahatan lingkungan. Terlebih lagi masyarakat kurang perduli terhadap kasus kejahatan lingkungan tersebut, karena dampaknya baru disadari oleh masyarakat setelah terjadi musibah terhadap diri mereka, misalnya : banjir, longsor, kekeringan sesak napas, demam berdarah dan sebagainya. Meningkat sangat besarnya kerugian yang di timbulkan oleh pencemaran atau pengrusakan kawasan hutan, maka terhadap pelakunya perlu diambil tindakan tegas yang berupa penuntutan dan pengadilan atau dengan kata lain perlu di adakan penegakan hukum pidana secara tegas kepada mereka yang melanggar ketentuan-ketentuan yang diatur dalam Undang-Undang Nomor 23 Tahun 1997 tentang Pengelolaan Lingkungan Hidup(selanjutnya di sebut UUPLH) yang kemudian diganti dengan Undang-Undang Nomor 32 Tahun 2009.

Penegakan hukum disini diharapkan sebagai salah satu upaya penanggulangan terhadap tindak pidana illegal logging berdasarkan hukum yang telah ada, yang mana sebagai akibat dari illegal logging ini dapat menimbulkan banyak kerugian baik pada pemerintah, hutan berserta lingkungan hidup dan ekosistemnya, masyarakat juga segala kehidupan yang mulai langka baik flora maupun faunanya.

Kewenangan Anggota Polhut apabila tertangkap tangan dalam tindak pidana kehutanan hanya sampai penangkapan tersangka dan pengamanan barang bukti. Tugas ini selanjutnya harus segera diserahkan kepada Penyidik Pegawai Negeri Sipil selanjutnya disingkat (PPNS) untuk diproses pemeriksaan lebih lanjut. PPNS Kehutanan berwenang melakukan penyidikan terhadap tindak kejahatan kehutanan (Pasal 78 Undang-Undang Nomor 41 Tahun 1999). Selanjutnya PPNS Kehutanandan penyidik Polri melakukan tugas lex specialist, karena itu PPNS harus lebih menguasai bidangnya dibandingkan dengan Penyidik Polri.

Untuk menjamin kelancaran penyidikan dibidang pidana kehutanan, seharusnya penyidikan dilakukan oleh PPNS bekerjasama dengan Penyidik Polri. Pengalaman menunjukkan bahwa penyidikan yang dilakukan sendiri lebih cepat, murah dan tepat. Secara informal PPNS harus memonitor 
perkembangan kasus apa yang sudah divonis dan berapa lama vonisnya.

Selain itu, saksi ahli sedapat mungkin harus dari instansi kehutanan karena secara keilmuan dan pengalaman dia lebih menguasai dibidangnya dibandingkan dengan institusi lain. Koordinasi formal dan informal harus dibina dan ditingkatkan diantara penegak hukum (Polisi, Jaksa dan Pengadilan). Pengalaman menunjukkan bahwa hubungan informal jauh lebih efektif daripada formal.

Untuk lebih meningkatkan kewenangan penyidik, perlu dilakukan penyempurnaan terhadap KUHAP terutama yang berkaitan dengan tugas dan wewenang PPNS antara lain meliputi penangkapan dan penahanan tersangka, penyampaian berkas kepada penuntut umum "melalui" penyidik Polri. Kata-kata penangkapan, penahanan dan melalui sering menghambat kelancaran tugas-tugas PPNS terutama apabila ada "interest tertentu" oleh Penyidik Polri. Padahal Pasal 6 ayat 1 Kitab Undang-undang Hukum Acara Pidana selanjutnya disingkat dengan (KUHAP) menyebutkan kedudukan PPNS dan Penyidik Polri adalah sama.PPNS Kehutanan adalah pejabat pegawai negeri sipil tertentu dalam lingkup instansi kehutanan pusat dan daerah yang oleh undangundang diberi wewenang khusus penyidikan di bidang kehutanan dan konservasi sumber daya alam hayati dan ekosistemnya. (Peraturan Pemerintah Nomor 45 Tahun 2004)

Pegawai Negeri Sipil untuk dapat menjadi Penyidik Pegawai Negeri Sipil (PPNS) harus memenuhi syarat kepangkatan dan pengangkatan sesuai ketentuian Pasal
2 Peraturan Pemerintah Nomor. 27 tahun 1983 yaitu:

1. Pejabat pegawai negeri sipil tertentu yang sekurangkurangnya berpangkat Pengatur Muda Tingkat I (golongan II/b) atau yang disamakan dengan itu.

2. Diangkat oleh Menteri Kehakiman atas usul dari departemen yang membawahkan pegawai negeri tersebut, Menteri sebelum melaksanakan terlebih dahulu mendengar pertimbangan Jaksa Agung dan KaPolri.

KUHAP tidak memberikan wewenang secara rinci kepada PPNS sebagaimana penyidik Polri di atas, Pasal 7 ayat (2) KUHAP menyebutkan bahwa PPNS mempunyai wewenang sesuai dengan undang-undang yang menjadi dasar hukumnya masing-masing.

Kewenangan PPNS kehutanan disebutkan secara limitatif dalam Pasal 77 ayat (2) Undang-Undang Nomor 41 Tahun 1999, yaitu bahwa PPNS berwenang untuk:

1. Melakukan pemeriksaan atas kebenaran laporan atau keterangan yang berkenaan dengan tindak pidana yang menyangkut hutan, kawasan hutan, dan hasil hutan;

2. Melakukan pemeriksaan terhadap orang yang diduga melakukan tindak pidana yang menyangkut hutan, kawasan hutan, dan hasil hutan;

3. Memeriksa tanda pengenal seseorang yang berada dalam kawasan hutan atau wilayah hukumnya;

4. Melakukan penggeledahan dan penyitaan barang bukti tindak pidana yang menyangkut hutan, kawasan hutan, dan hasil hutan sesuai dengan ketentuan 
peraturan perundang-undangan yang berlaku;

5. Meminta keterangan dan barang bukti dari orang atau badan hukum sehubungan dengan tindak pidana yang menyangkut hutan, kawasan hutan, dan hasil hutan;

6. Menangkap dan menahan dalam koordinasi dan pengawasan penyidik Kepolisian Negara Republik Indonesia sesuai dengan KUHAP;

7. Membuat dan menandatangani berita acara;

8. Menghentikan penyidikan apabila tidak terdapat cukup bukti tentang adanya tindak pidana yang menyangkut hutan, kawasan hutan, dan hasil hutan.

Penulis berpendapat bahwa kewenangan PPNS Kehutanan sebagaimana disebutkan dalam undang-undang kehutanan kurang lengkap karena tidak mengadopsi ketentuan-ketentuan yang mendasar bagi penyidik untuk melakukan penyidikan yaitu tidak diberikannya kewenangan secara tegas oleh undang-undang untuk melakukan tindakan pertama pada saat di tempat kejadian perkara; menyuruh berhenti seorang tersangka dan memeriksa tanda pengenal diri tersangka; memanggil orang untuk didengar dan diperiksa sebagai tersangka atau saksi; dan mendatangkan orang ahli yang diperlukan dalam hubungannya dengan pemeriksaan perkara.

PPNS Kehutanan dalam
melaksanakan kewenangannya
sebagai penyidik tidak menjadi
subordinasi dari penyidik Polri tetapi
hanya di bawah koordinasi dan
pengawasan penyidik Polri, adapun
bentuk koordinasi dan
pengawasannya telah diatur dalam
Pasal 107 KUHAP yaitu:

1. Untuk kepentingan penyidikan penyidik Polri memberi petunjuk dan bantuan penyidikan kepada PPNS (Pasal 107 ayat (1));

2. Dalam hal suatu peristiwa yang patut diduga merupakan tindak pidana sedang dilakukan penyidikan oleh PPNS kemudian ditemukan bukti yang kuat untuk diajukan kepada penuntut umum maka PPNS melaporkan hal ini kepada penyidik Polri (Pasal 107 ayat (2)), dalam ketentuan KUHAP tidak disebutkan bahwa PPNS harus memberitahukan (melaporkan) dimulainya penyidikan kepada penuntut umum hal ini diatur dalam Pasal 77 ayat (3) Undang-Undang Nomor 41 Tahun 1999;

3. Dalam hal perkara pidana telah selesai disidik oleh PPNS, maka hasil penyidikannya diserahkan kepada penuntut umum melalui penyidik Polri (Pasal 107 ayat (3)), untuk penyerahan berkas perkara ini juga diatur dalam ketentuan Pasal 77 ayat (3) undang-undang kehutanan yang menyebutkan bahwa PPNS memberitahukan dimulainya penyidikan dan menyerahkan hasil penyidikannya kepada penuntut umum sesuai ketentuan KUHAP;

4. Dalam hal PPNS menghentikan penyidikan maka penghentian penyidikan tersebut harus diberitahukan kepada penyidik Polri dan penuntut umum. (Pasal 109 ayat (3) KUHAP).

Penyelidikan adalah serangkaian tindakan penyelidik untuk mencari dan menemukan suatu peristiwa yang diduga sebagai tidak pidana guna menentukan dapat atau tidaknya dilakukan penyidikan menurut cara yang diatur dalam 
undang-undang ini (Pasal 1 angka 5 KUHAP), penyelidik adalah pejabat polisi negara Republik Indonesia yang diberi wewenang oleh undangundang ini untuk melakukan penyelidikan (Pasal 1 angka 4 KUHAP). Menurut Pasal 4 KUHAP penyelidik adalah setiap pejabat polisi negara Republik Indonesia. dari ketentuan ini maka dapat diartikan bahwa:

1. Penyelidik adalah setiap pejabat polisi negara Republik Indonesia, dari pangkat terendah sampai pangkat tertinggi;

2. Tidak ada pejabat lain yang berkedudukan sebagai penyelidik dan berwenang melakukan penyelidikan.

Wewenang penyelidik menurut ketentuan Pasal 5 KUHAP adalah: a. Karena kewajibannya mempunyai wewenang:

1. Menerima laporan dan pengaduan tentang tindak pidana;

2. Mencari keterangan dan barang bukti;

3. Menyuruh berhenti seseorang yang dicurigai dan menanyakan serta memeriksa tanda pengenal diri;

4. Mengadakan tindakan lain menurut hukum yang bertanggung jawab.

b. Atas perintah penyidik dapat melakukan tindakan berupa:

1. Penangkapan, larangan meninggalkan tempat, penggeledahan dan penyitaan;

2. Pemeriksaan dan penyitaan surat;

3. Mengambil sidik jari dan memotret seseorang;

4. Membawa dan menghadapkan seseorang kepada penyidik.
Untuk

menjamin terselenggaranya perlindungan hutan, dalam ketentuan Pasal 51 UndangUndang Nomor 41 Tahun 1999, pejabat kehutanan tertentu diberi wewenang kepolisian khusus yang kewenangannya mirip dengan kewenangan penyelidik Polri. Pasal 32 ayat (2) Peraturan Pemerintah Nomor 45 Tahun 2004 tentang Perlindungan Hutan menyebutkan bahwa pejabat kehutanan tertentu yang diberi wewenang kepolisian khusus meliputi :

1. Pegawai negeri sipil yang diangkat sebagai pejabat fungsional polisi kehutanan;

2. Pegawai perusahaan umum kehutanan Indonesia (perum perhutani) yang diangkat sebagai polisi kehutanan;

3. Pejabat struktural instansi kehutanan pusat maupun daerah yang sesuai dengan tugas dan fungsinya berwenang dan tanggungjawab dibidang perlindungan hutan.

Pejabat yang diberi wewenang kepolisian khusus tersebut di atas dalam ketentuan Pasal 51 ayat (2) Undang-Undang Nomor 41 Tahun 1999 dan Pasal 36 ayat (3) Peraturan Pemerintah Nomor 45 Tahun 2004 diberi wewenang untuk:

1. Mengadakan patroli/perondaan di dalam kawasan hutan atau wilayah hukumnya;

2. Memeriksa surat-surat atau dokumen yang berkaitan dengan pengangkutan hasil hutan di dalam kawasan hutan atau wilayah hukumnya;

3. Menerima laporan tentang telah terjadinya tindak pidana yang menyangkut hutan, kawasan hutan, dan hasil hutan;

4. Mencari keterangan dan barang bukti terjadinya tindak pidana 
yang menyangkut hutan, kawasan hutan dan hasil hutan;

5. Dalam hal tertangkap tangan, wajib menangkap tersangka untuk diserahkan kepada yang berwenang; dan

6. Membuat laporan dan menandatangani laporan tentang terjadinya tindak pidana yang menyangkut hutan, kawasan hutan dan hasil hutan.

Pasal 36 ayat (3) Peraturan Pemerintah Nomor 45 Tahun 2004 menyebutkan bahwa atas perintah pimpinan polisi kehutanan berwenang untuk melakukan penyelidikan, dalam rangka mencari dan menangkap tersangka. Dengan demikian walaupun undang-undang kehutanan dan peraturan pelaksananya tidak secara inplisit memberi wewenang kepada pejabat kehutanan tertentu untuk dapat menjadi penyelidik dan melakukan tugas-tugas penyelidikan sebagaimana penyelidik Polri, kewenangan tersebut melekat pada tugas dan kewenangan polisi kehutanan, yang membedakannya yaitu:

1. Kewenangan tugas polisi kehutanan terbatas hanya pada tindak pidana dibidang kehutanan sedangkan penyelidik Polri untuk semua tindak pidana;

2. Polisi kehutanan tidak memiliki kewenangan untuk menyuruh berhenti seseorang yang dicurigai dan menanyakan serta memeriksa tanda pengenal diri sebagaimana penyelidik Polri, menurut saya seharusnya polisi kehutanan memiliki kewenangan ini, karena merupakan langkah awal melaksanakan kewenangan berikutnya untuk memeriksa surat-surat atau dokumen yang berkaitan dengan pengangkutan hasil hutan di dalam kawasan hutan atau wilayah hukumnya.

3. Polisi kehutanan tidak memiliki kewenangan untuk mengadakan tindakan lain menurut hukum yang bertanggung jawab sebagaimana penyelidik Polri, menurut saya ketentuan ini seolah-olah memberikan keleluasaan bertindak bagi penyelidik namun jika diselaraskan dengan persyaratan sebagaimana yang disebutkan dalam penjelasan ayat tersebut, sulit menemukan bentuk konkrit dari tindakan lain menurut hukum yang bertanggungjawab yang memenuhi standar persyaratan, sehingga tidak memberi kepastian hukum bagi penyelidik, hal ini dapat menimbulkan tindakan sewenang-wenang penyelidik, namun bisa juga menjadi bumerang bagi penyelidik jika tindakannya dinilai sebagai perbuatan melawan hukum, untuk itu ketentuan ini tidak perlu diadopsi oleh undangundang kehutanan.

4. Polisi kehutanan kecuali tertangkap tangan untuk melakukan penangkapan harus ada perintah pimpinan, sedangkan penyelidik Polri perintah berasal dari penyidik.

5. Polisi kehutanan tidak memiliki kewenangan untuk melakukan penyitaan dan penggeledahan sebagaimana penyelidik Polri atas perintah penyidik, menurut saya atas perintah pimpinan selain memiliki kewenangan untuk melakukan penangkapan Polisi kehutanan seharusnya juga diberi wewenang untuk melakukan penyitaan dan 
penggeledahan dalam rangka membantu tugas PPNS.

6. Polisi kehutanan tidak memiliki kewenangan membawa dan menghadapkan seseorang kepada penyidik sebagaimana penyelidik Polri yang atas perintah penyidik dapat membawa dan menghadapkan seseorang kepada penyidik.

Penyelidikan merupakan tahapan awal proses perkara pidana yang tidak dapat dipisahkan dengan penyidikan, dengan penyelidikan penyelidik dapat memberikan informasi data dan fakta yang akurat kepada penyidik sehingga penyidik dapat segera menentukan sikap apakah dapat dilakukan penyidikan, ditunda atau tidak perlu dilakukan penyidikan, kemudian dari hasil penyelidikan penyidik telah memiliki persiapan yang matang untuk melakukan tindakan penyidikan, sehingga semaksimal mungkin akan dapat dihindari kesalahan dalam penggunaan tindakan upaya paksa yang berakibat proses praperadilan.

Penulis berpendapat bahwa khusus untuk tindak pidana yang menyangkut hutan, kawasan hutan dan hasil hutan selain penyelidik Polri pejabat kehutanan tertentu hendaknya diberikan kewenangan khusus oleh undang-undang kehutanan secara tegas untuk dapat menjadi penyelidik dan melakukan penyelidikan sebagaimana penyelidik Polri, hanya dibatasi saja lingkup tugas dan wewenangnya dalam ketentuan undangundang.Untuk kepentingan penyidikan perkara tindak pidana Kehutanan:

1. Penyidik Polri (Pasal 7 ayat (1) huruf d jo. Pasal 16 ayat (2) KUHAP);
2. Penyidik pembantu (Pasal 16 ayat (2) KUHAP),

3. Penyelidik atas perintah penyidik (Pasal 5 ayat (1) huruf b angka 1 jo. Pasal 16 ayat (1) KUHAP),

4. PPNS Kehutanan (Pasal 77 ayat (2) huruf f Undang-Undang No. 41 Tahun 1999,

5. Polisi Kehutanan atas perintah pimpinan (Pasal 36 ayat (3) PP No. 45 Tahun 2004, dan

6. setiap orang (Pasal 111 ayat (1) KUHAP (tertangkap tangan).

Banyaknya orang yang memiliki kewenangan melakukan penangkapan, tidak sejalan dengan pengertian penangkapan sebagaimana yang tertuang dalam Pasal 1 butir 20 KUHAP bahwa penangkapan merupakan monopoli tindakan penyidik.Pasal 1 butir 20 KUHAP menyebutkan bahwa penangkapan adalah suatu tindakan penyidik berupa pengekangan sementara waktu kebebasan tersangka atau terdakwa apabila terdapat cukup bukti guna kepentingan penyidikan atau penuntutan dan atau peradilan dalam hal serta menurut cara yang diatur dalam undang-undang ini.

Harahap (2005) menyatakan bahwa pengertian bukti permulaan yang cukup hampir serupa dengan apa yang dirumuskan Pasal 183 KUHAP, yaitu harus berprinsip pada "batas minimal pembuktian" yang terdiri sekurang-kurangnya dua alat bukti bisa terdiri dari dua orang saksi atau saksi ditambah satu alat bukti lain.

Ketentuan pelaksanaan penangkapan terhadap tersangka tindak pidana kehutanan adalah sebagai berikut:

1. Dilaksanakan oleh petugas kepolisian negara Republik 
Indonesia dengan memperlihatkan surat tugas dan memberikan surat perintah penangkapan yang mencantumkan identitas tersangka dan menyebutkan alasan penangkapan serta uraian singkat perkara kejahatan yang dipersangkakan serta tempat ia diperiksa (Pasal 18 ayat (1) KUHAP);

2. Jika PPNS kehutanan ingin melakukan penangkapan (dalam hal bukan tertangkap tangan) maka mengirimkan surat permohonan bantuan penangkapan kepada Polri;

3. Dalam hal tertangkap tangan penangkapan dilakukan tanpa surat perintah, dengan ketentuan bahwa penangkapan harus segera menyerahkan tersangka beserta barang bukti yang ada kepada penyidik atau penyidik pembantu terdekat (Pasal 18 ayat (2) KUHAP);

4. Tembusan surat perintah penangkapan harus diberikan kepada keluarganya segera setelah penangkapan dilakukan (Pasal 18 ayat (3) KUHAP);

5. Penangkapan dapat dilakukan paling lama satu hari (Pasal 19 ayat (1) KUHAP).

Undang-undang kehutanan dan peraturan pelaksananya telah memberikan wewenang kepada PPNS dan polisi kehutanan atas perintah pimpinan untuk dapat melakukan penangkapan, namun tidak diatur mekanismenya dan menyerahkannya kepada KUHAP, sedangkan menurut KUHAP selain tertangkap tangan yang memiliki kewenangan melakukan penangkapan hanyalah petugas kepolisian negara republik indonesia.
Ketidaklengkapan pengaturan mekanisme penangkapan oleh PPNS kehutanan dan polisi kehutanan dalam undang-undang kehutanan menimbulkan beda persepsi penerapannya bahkan menyebabkan kewenangan tersebut "mandul" sehingga dalam hal tidak tertangkap tangan PPNS masih meminta bantuan Polri untuk mengeluarkan surat perintah penangkapan dengan membuat permintaan bantuan penangkapan ke kepolisian terdekat meskipun polisi kehutanan dan PPNS kehutanan sudah memiliki kewenangan itu berdasarkan undangundang.

\section{Penutup}

Undang-undang kehutanan dan peraturan pelaksananya telah memberikan wewenang kepada PPNS dan polisi kehutanan atas perintah pimpinan untuk dapat melakukan penangkapan, namun tidak diatur mekanismenya dan menyerahkannya kepada KUHAP, sedangkan menurut KUHAP selain tertangkap tangan yang memiliki kewenangan melakukan penangkapan hanyalah petugas Kepolisian Negara Republik Indonesia. Ketidaklengkapan pengaturan mekanisme penangkapan oleh PPNS kehutanan dan polisi kehutanan dalam undang-undang kehutanan menimbulkan beda persepsi penerapannya bahkan menyebabkan kewenangan tersebut "mandul" sehingga dalam hal tidak tertangkap tangan PPNS masih meminta bantuan POLRI untuk mengeluarkan surat perintah penangkapan dengan membuat permintaan bantuan penangkapan ke kepolisian terdekat meskipun polisi kehutanan dan PPNS kehutanan sudah memiliki kewenangan itu 
berdasarkan undang-undang. Berdasarkan keterangan di atas maka dapat disimpulkan bahwa pelaksanaan kewenangan penyidikan, penyelidikan, dan penahanan pada kasus illegal logging antara Polhut, PPNS, dan Penyidik Polri ada tumpang tindih dan ketidakjelasan pengaturannya sehingga menimbulkan persepsi atau penafsiran-penafsiran yang berbeda antar penegak hukum sendiri.

\section{Daftar Pustaka}

Absori. 2000. Penegakan Hukum Lingkungan \& Antisipasi dalam Era Pembangunan Bebas. Muhammadiyah University Press.

Amsyari, Fuad. 1981. PrinsipPrinsip Masalah Pencemaran Lingkungan. Cetakan kedua. Ghalia Indonesia, Jakarta.

Ariman, M. Rasyid. 1988. Fungsi Hukum Pidana Terhadap Perbuatan Pencemaran Lingkungan Hidup. Ghalia Indonesia, Jakarta.

Danusaputro, Munadjad. 1985. Hukum Lingkungan, Buku I Umum. Bina Cipta, Bandung.

Hardjasoemantri, Koesnadi.1992. Menjelang Sepuluh Tahun Undang-Undang Hukum Lingkungan Hidup. Gadjah Mada University Press, Yogyakarta.

$\begin{array}{lr}\text { Tata Lingkungan. } & \text { Gadjah } \\ \text { Mada University } & \text { Press, } \\ \text { Yogyakarta. } & \end{array}$

Hamdan, M. 1997. Politik Hukum Pidana. Raja Grafindo Persada, Jakarta.

Hamid, Hamrat. 1991. Pedoman Penegakan Hukum Lingkungan Kejaksaan Agung RI, Jakarta.
Husein, M. Harun. 1995. Lingkungan Hidup: Masalah, Pengelolaan, dan Penegakan Hukum. Bina Aksara, Jakarta.

Rangkuti, Siti Sundari. 1984. Sanksi Pidana dalam Hukum Lingkungan. FH-Universitas Airlangga, Surabaya.

Silalahi, M. Daud. 1992. Hukum Lingkungan dalam Sistem Penegakan Hukum Lingkungan Indonesia. Alumni, Bandung.

Soekanto, Soerjono. 1986. FaktorFaktor yang Mempengaruhi Penegakan Hukum. Rajawali, Jakarta.

Soemarwoto, Otto. 1989. Analisis Dampak Lingkungan. Gadjah Mada University Press, Yogyakarta.

Subagyo, P. Joko. 1999. Hukum Lingkungan Masalah dan Penanggulangannya. Rineka Cipta, Jakarta.

Sudarto. 1986. Hukum dan Hukum Pidana. Alumni, Bandung.

Usman, Rachmadi. 2003, Pembaharuan Hukum Lingkungan Nasional. Citra Aditya Bakti, Bandung.

Wahjono, Padmo. Pembangunan Hukum di Indonesia. Ind.-Hill Co., Jakarta.

Undang-Undang Nomor 8 tahun 1981 tentang Kitab UndangUndang Hukum Acara Pidana.

Undang-Undang Nomor 41 Tahun 1999 tentang Kehutanan.

Undang-Undang Nomor 2 Tahun 2002 tentang Kepolisian Negara Republik Indonesia.

Undang-Undang Nomor 32 Tahun 2009 tentang Perlindungan dan Pengelolaan Lingkungan Hidup. 